\title{
CLO WYCHOWAWCZE W UJĘCIU SZKOEY KLASYCZNEJ I NIEMIECKIEJ SZKOLY HISTORYCZNEJ Z UWZGLĘDNIENIEM NIEMIECKIEGO PRZEMYSŁU HUTNICZEGO
}

\begin{abstract}
Streszczenie
Cło wychowawcze jest ciagle ważnym narzędziem polityki handlowej dotyczącym ochrony rozwijających się rodzimych (krajowych) nowych dziedzin gospodarki (przemysłu). Mimo powszechnej krytyki ze strony nurtu klasycznego w ekonomii, należy uznać, że poglądy reprezentowane przez szkoły będące w opozycji, w tym niemieckiej szkoły historycznej i Friedricha Lista, mają swoje solidne podstawy i nie mogą być ignorowane nawet we współczesnej gospodarce. Model ekonomiczny z uwzględnieniem polityki ceł wychowawczych jest właściwy metodologicznie, natomiast może być trudny w realizacji w warunkach realnej gospodarki. Zakładając jednak, że cło wychowawcze jest narzędziem tymczasowym, a docelowym etapem wolna wymiana handlowa, może ono przynieść wymierne korzyści zarówno dla kraju, jak i dobrobytu społecznego świata.

Autor zobrazował poglądy ekonomistów szkoły klasycznej i neoklasycznej oraz szkoły niemieckiej odnoszące się do oceny wpływu ceł wychowawczych z wykorzystaniem dobrobytu społecznego. Posłużył się również przykładami liczbowymi dotyczącymi ochrony przemysłu w Wielkiej Brytanii i Niemczech. Ważnym elementem była analiza polityki celnej Niemiec obejmująca przemysł hutniczy w XIX i początkach XX wieku.
\end{abstract}

Słowa kluczowe: cło wychowawcze, szkoła klasyczna, niemiecka szkoła historyczna, Friedrich List

\section{PROTECTIVE CUSTOMS DUTY: THE ACHIEVEMENTS OF CLASSICAL SCHOOL AND HISTORICAL GERMAN SCHOOL AS EXEMPLIFIED BY GERMANY'S IRON AND STEEL INDUSTRY}

\section{Summary}

The protective customs duty is still an important tool for the protection of trade policy of developing domestic (national) sectors of the economy (industry). In spite of widespread criticism from the classical school of economics, one should admit that the views of its opponents, including the German historical school have a sound basis and cannot be ignored, even in the contemporary economy. The founder of the school, Friedrich List, argues that the protection of an infant industry is necessary for countries at early stages of industrialization. Although the economic model involving protective custom duties is methodologically correct, it can be difficult to implement in a real economy. Assuming, however, that the protective customs duty is a temporary tool, and that free trade is the ultimate aim, it is likely to bring tangible benefits for both the country and the social welfare of the world.

Key words: educational duty, classical school, the German historical school, Friedrich List

${ }^{1}$ Dr Janusz Myszczyszyn - Wydział Ekonomiczny, Zachodniopomorski Uniwersytet Technologiczny w Szczecinie; e-mail: jmyszczyszyn@zut.edu.pl. 


\section{Wstęp}

Kraje rozwinięte gospodarczo stanowią około 15\% ludności świata, ale jednocześnie generują około $60 \%$ produkcji i wymiany międzynarodowej. Stąd też można przypuszczać, że ich gospodarki są bardziej efektywne (rozwinęła się konkurencja) i z powodzeniem angażują się w wymianę światową. Kraje aspirujące do grona krajów rozwiniętych gospodarczo nie bez powodu upatruja w polityce protekcjonistycznej, w tym w odpowiednim ukształtowaniu polityki handlowej, źródeł sukcesu gospodarczego.

Konieczność ograniczania importu dóbr ze względu na potrzebę ochrony własnego rynku, a także nowo powstałych gałęzi przemysłu jest podnoszona od kilkuset lat. Ideę dodatniego bilansu handlowego popierali zarówno przedstawiciele merkantylizmu, jak i fizjokratyzmu.

Przedstawiciele ekonomii klasycznej wskazywali również sytuacje, w których należałoby zrezygnować z polityki liberalnej (wolnego handlu) i chronić własny rynek. W XIX wieku do zwolenników polityki ochrony rozwijających się przemysłów dołączyli m.in. przedstawiciele niemieckiej szkoły historycznej, w tym jej protoplasta Friedrich List.

Autor postawił hipotezę badawcza, że polityka cła wychowawczego, choć wydaje się sprzeczna z ideą wolnego handlu, była i pozostaje ważnym etapem ochrony powstających, rodzimych branż gospodarki (infant industry) przed napływem towarów z zagranicy. Bariera celna dla towarów zagranicznych umożliwia rozwój i podniesienie konkurencyjności krajowych gałęzi gospodarki, a w rezultacie może w przyszłości przyczynić się do powiększenia dobrobytu światowego. Poważnym zagrożeniem prowadzenia polityki ceł wychowawczych jest podatność decydentów na naciski polityczne (lobbing) czy wypaczenie mechanizmów rynkowych.

Warunkiem koniecznym do zapewnienia konkurencyjności i osiągnięcia nadwyżki konsumenta jest stopniowa rezygnacja z zaostrzonej polityki celnej i zastosowanie polityki liberalizacji ceł, łącznie z propagowaniem polityki wolnego handlu (free trade).

W pracy zostały wykorzystane liczne dane statystyczne dotyczace wymiany handlowej i stawek celnych w warunkach XIX i początkach XX wieku, a także poglądy ekonomistów klasycznych na tle stadiów rozwoju Friedricha Lista.

\section{Argumenty na rzecz cła wychowanego w aspekcie równowagi ogólnej - postulaty szkoły neoklasycznej}

Klasyczna teoria handlu powstała pod koniec XVIII wieku, jej prekursorem był „ojciec ekonomii” A. Smith, a twórcą D. Ricardo. Sama idea wolnego handlu po raz pierwszy pojawiła się w 1776 roku w dziele A. Smitha pt.: Bogactwo narodów (ang. The Wealth of Nations), [Smith, 1954]. Smith wskazał, że eliminacja barier handlowych pozwala na specjalizację w tych gałęziach produkcji, dla których w danym kraju występuja najkorzystniejsze warunki. Podstawą teorii była analiza różnic w bezwzględnych kosztach produkcji dobra. Źródłami tej przewagi mogły być: powszechny dostęp do zaawan- 
sowanej technologii, większa efektywność zasobów, większa wydajność pracy itd. [Rynarzewski, Zielińska-Głębocka, 2006, s. 63 i n.].

Sytuacja kraju, który nie ma przewagi absolutnej w produkcji żadnego dobra, zainspirowała D. Ricardo do badań kosztów względnych. W swoim dziele z 1817 roku pt.: Zasady ekonomii politycznej $i$ opodatkowania (ang. On the Principles of Political Economy and Taxation) [Ricardo, 1957] konstatował, że w Portugalii względny koszt produkcji wina był niższy niż produkcji tkanin, stąd Portugalia powinna się specjalizować w produkcji wina, a importować tkaniny z Anglii [Ricardo, 1823]. Prawo korzyści komparatywnych opierało się na definicji przewagi komparatywnej i kosztu komparatywnego. Zasada kosztów absolutnych i komparatywnych stały się fundamentami nowoczesnej teorii handlu międzynarodowego.

Polityka wolnego handlu była następstwem uprzemysłowienia, a nie jej skutkiem, czego dobitnym przykładem jest Anglia - jedyny kraj, w którym u zarania XIX wieku triumfowała industrializacja. Mimo zniesienia w 1814 roku ostatnich pozostałości ustawodawstwa cechowego, do systemu ceł ochronnych dotyczących wyrobów przemysłowych dołączono protekcjonizm agrarny (ustawy zbożowe, ang. corn-laws), [Kuliszer, 1961, s. 429, 493]. W tym okresie średnie cła wynosiły w: USA - 35-45\%, Danii 25-35\%, Prusach - 8-12\%, Holandii i Belgii 6-8\% [Bairoch, 1993, s. 40].

Dopiero w 1846 roku, w obliczu klęski nieurodzaju i śmierci głodowej wielu obywateli, w Anglii zniesiono symbol protekcjonizmu agrarnego - ustany zbożowe.

Okres obowiązywania ochrony w formie cła wychowawczego w Anglii cechował się selektywnościa, początkowo chroniono: produkty wełniane, bawełniane, żelazo. Następnie wprowadzono cła na import: innych metali, skór, statków, jedwabiu. Zbyt długie utrzymywanie ceł prowadziło do tego, że dopiero około połowy XIX wieku niektóre branże przemysłowe dojrzały do konkurencji na rynku krajowym i międzynarodowym. Anglia jest zatem przykładem stopniowego i selektywnego liberalizowania wymiany handlowej, zgodnie z koncepcja infant industry [McKee, 1934, s. 178-276].

Miarą stopnia protekcjonizmu mogą być przychody netto z ceł, a te w latach 1821-25 wynosiły aż 53,1\% wartości importu Wielkiej Brytanii (we Francji 20,3\%). W latach 1841-1845 spadły do 32,2\% importu (we Francji 17,9\%), aby w latach 1856-1860 wynieść 15\% (we Francji 10\%), [Dormois, Lains, 2006, s. 15].

Na poniższym rysunku (rysunek 1.) autor ukazał wyniki handlu zagranicznego Wielkiej Brytanii w latach 1800-1910 (mln £).

W początkowym okresie, mimo postępu w industrializacji, można zauważyć jedynie powolny wzrost wymiany handlowej. Skutkiem industrializacji były zmiany w przemyśle i rozwój rynku krajowego.

W 1840 roku wartość eksportu Wielkiej Brytanii wyniosła blisko $51,5 \mathrm{mln}$ £, czyli porównywalną wartość do 1815 roku. W takim samym okresie 25 lat, czyli w 1865 roku, wartość eksportu wyniosła już blisko $166 \mathrm{mln} £$, wzrastając ponad trzykrotnie. Stąd też związek pomiędzy prowadzoną polityką handlową po 1849 roku a wynikami handlu wydaje się oczywisty.

Jednocześnie po okresie liberalizacji ceł Wielka Brytania odnotowywała ujemne saldo wymiany zagranicznej. W latach 1820-1850, mimo dużych wahań, saldo wymiany nie przekraczało $20 \mathrm{mln} £$. Po tym czasie ujemne saldo systematycznie zwiększało się. 
Nadwyżka importu nad eksportem na początku XIX wieku sięgała 1/3 wartości brytyjskiego eksportu, zaś po pierwszej dekadzie XX wieku saldo to przekroczyło już niemal $60 \%$ eksportu ${ }^{2}$. Anglia stała się importerem tanich zbóż, innych produktów rolnych i surowców, będąc wiodącym eksporterem dóbr przemysłowych.

\section{Wyniki handlu zagranicznego Wielkiej Brytanii 1800-1910 (w mln £)}

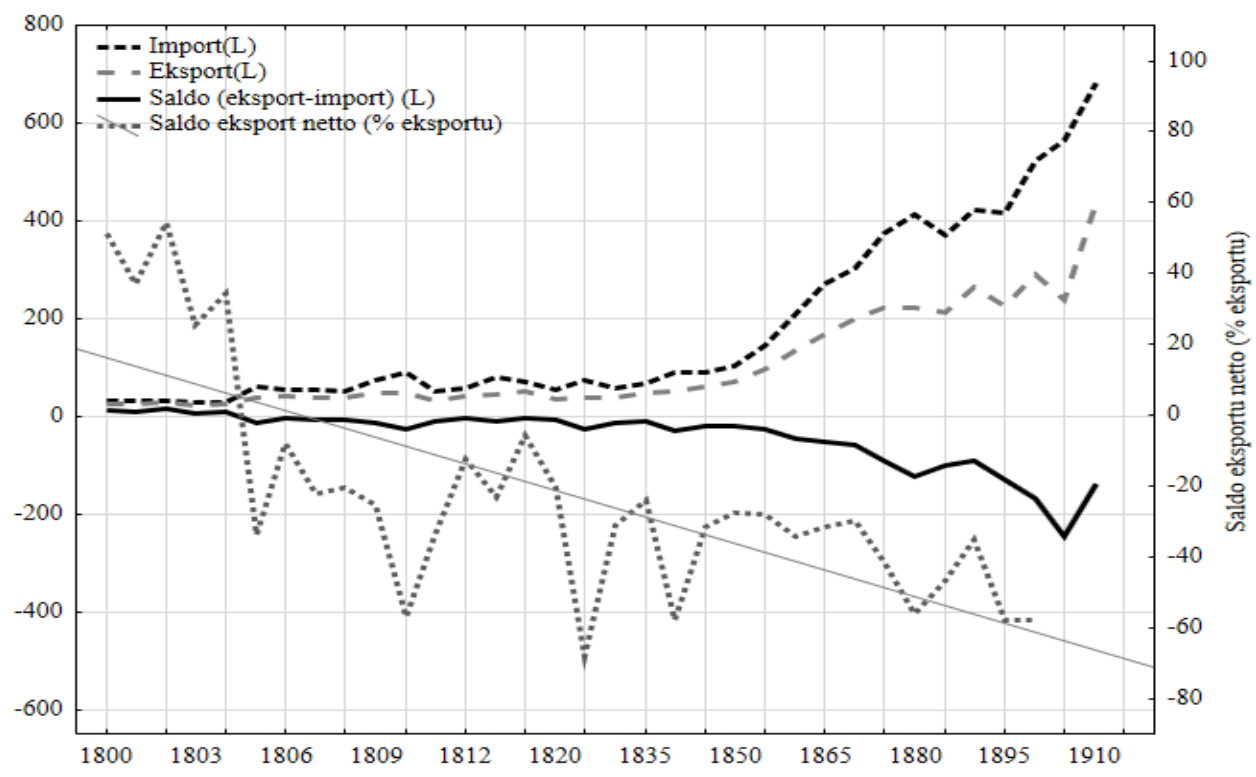

Źródło: obliczenia własne na podstawie: [Mitchell, 1988, s. 450-453].

Lata 1850-1870 to era wolnego handlu w Europie [Capie, 1994, s. 9]. Analizując średni poziom stawek celnych w latach 1857-1873 (Wielka Brytania, Niemcy, Francja, Belgia, Holandia, Austro-Węgry oraz USA), można zauważyć, że Wiellka Brytania posiadała najniższe cła na zboża i artykuły przemysłowe - najczęściej była to stawka $0 \%$, natomiast wyjątkiem były stawki celne na wino (inne wyroby spirytusowe), które choć wysokie, sięgające w 1857 roku 69\%, spadły w 1873 roku do $25,8 \%$.

W pozostałych gospodarkach krajów europejskich w ciagu 15 lat spadły stawki na artykuły przemysłowe, np.: dla surówki żelaza stawki obniżono nawet z $23 \%$ do 4\% (w Niemczech), z 19,1\% do 5,2\% (we Francji), przędzy bawełnianej z 36,1\% do $7,3 \%$ (we Francji), podobnie było w przypadku stali. W wielu przodujących gospodarczo krajach europejskich stawki celne dla importu zbóż zostały niemal całkowicie zniesione. Średnie stawki celne w Europie wyraźnie obniżyły się w latach siedemdziesiątych XIX wieku, osiagając kilka procent [Lampe, 2008, s. 140].

\footnotetext{
${ }^{2}$ W wieku XVIII Wielka Brytania notowała ujemne saldo bilansu handlowego, a wynikało to z importu dóbr kolonialnych.
} 
W Rosji i Hiszpanii taryfa celna na artykuły przemysłowe była ciagle wysoka i wynosiła 15-20\% [Bairoch, 1993, s. 40].

Kryzys złotego okresu wolnego handlu nastapił już w latach sześćdziesiątych XIX wieku (wojna domowa w USA) i po 1873 roku w Europie jako odzew na depresję oraz efekt żądań wybranych grup producentów ${ }^{3}$. Wówczas jedynie Wielka Brytania była krajem, który nadal prowadził politykę wolnego handlu.

Mimo nasilenia polityki protekcjonistycznej w końcu XIX wieku i po rozkładzie szkoły klasycznej, nowi klasycy ekonomii odnosili się z wyraźną rezerwą do stosowania cła wychowawczego, uzasadniając zalety wolnego handlu. Wykazywali ważne argumenty przeciw takiej ochronie. Jeden z przedstawicieli nurtu liberalnego, J. Viner zauważał, że ochrona celna oznacza:

- często mocno arbitralny wybór, która branża (sektor) będzie objęta ochrona:

- ochronę sektora, która ma swoje słabe uzasadnienie i niejako otwiera możliwości przewlekłości tego procesu;

- ochronę danej branży, która może stłumić lub opóźnić jej prawdziwy rozwój i budowę solidnych podstaw niezależności ekonomicznej jako wynik nadmiernej protekcji w stosunku do warunków rynkowych;

- $\quad$ niebezpieczeństwo, że ochrona stanie się zamiast tymczasowej trwała, co ograniczy możliwość wzrostu samodzielności sektora, również $\mathrm{w}$ relacjach $\mathrm{z}$ zagranica;

- utrzymanie trwałości ochrony jest szkodliwe dla ogółu społeczeństwa i jego dobrostanu [Viner, 1953, s. 60-73].

W połowie wieku XX było zauważalne dalsze zainteresowanie problematyka protekcji, z uzasadnieniem przykładów, w których byłoby wskazane zaangażowanie rządu w mechanizm rynkowy (niedoskonałości rynkowe, efekty zewnętrzne). W latach siedemdziesiątych XX wieku rozwinięto wiele nowych teorii handlu zagranicznego, w tym również model New Infant-Insustry P. Krugmana.

Ekonomiści, tacy jak: W. Leontief, P. Samuelson, E. Heckscher, B. Ohlin, połączyli teorie handlu zagranicznego $\mathrm{z}$ teoriami równowagi ogólnej. Stworzona przez nich teoria obfitości zasobów (model 2x2) zakłada, że kraj produkujący dwa dobra, obok pracy, używa względnie tańszego drugiego czynnika produkcji - kapitału lub ziemi.

Głównym wnioskiem jest stwierdzenie, że kraje powinny eksportować te dobra, do których produkcji zużywa się czynnika obfitszego w danym kraju, a importować te, których produkcja wymaga zużycia czynnika mniej obfitego.

W teorii Heckschera-Ohlina warunkiem koniecznym handlu międzynarodowego, gdy techniki produkcji w krajach są takie same, są różnice dotyczące podaży czynników produkcji. Ta różnica prowadzi do tego, że istnieją inne względne ceny tych czynników w obu krajach. Jeśli praca w stosunku do kapitału jest relatywnie tańsza w kraju A, to kraj ten ma przewagę w produkcji dóbr pracochłonnych. W kraju B, w którym praca jest relatywnie droższa niż kapitał, kraj ma przewagę w produkcji dóbr kapitałochłonnych. Wpływ tych różnic oznacza inny przebieg krzywych transformacji

\footnotetext{
${ }^{3}$ W Niemczech były to na przykład żądania junkrów pruskich i przemysłowców (,unia żelaza i żyta”).
} 
i układu kosztów komparatywnych. W rezultacie jeden kraj będzie specjalizował się w produkcji dóbr wymagających większych nakładów pracy, co w przyszłości (przy eksporcie swoich dóbr) doprowadzi do wzrostu popytu na pracę i wzrostu wynagrodzeń, a przy jednocześnie zmniejszonej produkcji dobra kapitałochłonnego nastapi spadek cen kapitału. W kraju, w którym będzie stosować się techniki kapitałochłonne, dostosowania będą podobne - cena kapitału wzrośnie, a pracy spadnie. W efekcie można będzie obserwować wyrównywanie się cen czynników produkcji [Ohlin, 1933; Heckscher, 1919].

Wymiana międzynarodowa nie pozostaje więc bez wpływu na cenę i podaż krajowych czynników produkcji. Efekt zmian w produkcji dwóch dóbr z uwzględnieniem oddziaływania wymiany zagranicznej został zobrazowany na rysunku 2 .

Krzywa transformacji dla kraju z autarkia gospodarcza przedstawia poziom produkcji dobra X, które wymaga znacznych nakładów pracy, a z kolei Y relatywnie dużych zasobów ziemi. Kraj jest bogaty w zasoby pracy. Preferencje konsumenta pozwalają na określenie punktów konsumpcji/produkcji na krzywej transformacji (punkt $\left.E_{C}\right)$. Linia ceny $P_{C}$ jest styczna do tego punktu.

W przypadku rezygnacji kraju z autarkii gospodarczej i włączenia się w wymianę międzynarodową zmienia się położenie linii ceny z $\mathrm{P}_{\mathrm{C}}$ do $\mathrm{P}_{\mathrm{w}}$. Optimum produkcji znajduje się w punkcie $E_{w}$. Zwiększone zapotrzebowanie z zagranicy, w tym specjalizacja, wpływa na wzrost wolumenu produkcji dobra X, a w konsekwencji wzrost płac, w tym samym czasie nie zmienia się podaż dobra Y. To prowadzi do wzrostu wyposażenia gospodarki w czynniki produkcji i w ten sposób przesunięcia krzywej transformacji do $T_{2}$. Ze względu na specjalizację dużo szybciej wzrastają możliwości zwiększenia produkcji pracochłonnego dobra X niż dobra $\mathrm{Y}$.

Położenie punktu optymalnej produkcji na krzywej $\mathrm{T}_{2}$ będzie uzależnione od wpływu kraju na poziom cen światowych, jeśli założymy, że kraj wytwarzający dobro $\mathrm{X}$ takiego wpływu nie ma, to linia ceny $\mathrm{P}_{\mathrm{w} 1}$ przesunie się równolegle do linii $\mathrm{P}_{\mathrm{w}}$, a punkt styczności będzie wyznaczał nowy punkt optimum $\left(\mathrm{E}_{\mathbb{W} 1}\right)$. Oznacza to dalszy wzrost produkcji dobra X i spadek produkcji dobra Y. Opisane powyżej zależności po raz pierwszy zostały przedstawione przez uczonego angielskiego Rybczyńskiego [Adebahr, Maennig, 1987, s. 67-68].

Jeśli kraj, który włącza się do wymiany handlowej, ma wpływ na ukształtowanie się nowej ceny światowej na dobro $\mathrm{X}$, wówczas linia ceny $\mathrm{P}_{\mathrm{w} 1}$ nie będzie położona równolegle do linii $\mathrm{P}_{\mathrm{W}}$. Stąd też zupełnie inne może być położenie punktu $\mathrm{E}_{\mathrm{W} 1 .}$

Wykorzystując dorobek neoklasyków, na poniższym rysunku zobrazowano możliwy efekt wprowadzenia cła wychowawczego (rysunek 3.).

W początkowym stadium rozwoju przemysłu w danym kraju możliwości produkcji dwóch dóbr X (dobro rolnicze, np. pszenica) i Y (dobro przemysłowe, np. surówka żelaza) zostały zilustrowane $\mathrm{z}$ użyciem krzywej transformacji $\mathrm{T}_{1}$. Założywszy, że kraj jest uczestnikiem wolnej wymiany handlowej, jego własne możliwości produkcji wynosza: $\mathrm{X}_{0}$ oraz $\mathrm{Y}_{0}$. Konsumpcja krajowa tych dwóch dóbr (przy cenie światowej $\mathrm{P}_{\mathrm{w}}$ jest określona w punkcie $\mathrm{C}_{\mathbb{W}} \mathrm{i}$ wynosi: $\mathrm{X}_{\mathbb{W}}$ oraz $\mathrm{Y}_{\mathrm{W}}$ ). Prowadząc wymianę międzynarodowa, analizowany kraj eksportuje nadwyżki pszenicy $\left(\mathrm{X}_{0}-\mathrm{X}_{\mathrm{w}}\right)$ i uzupełnia, importując, niedobór surówki żelaza $\left(\mathrm{Y}_{\mathrm{W}}-\mathrm{Y}_{0}\right)$. 
RYSUNEK 2. Wpływ wymiany międzynarodowej na przebieg krzywych transformacji, poziom cen i optimum produkcji (teoria Rybczyńskiego)

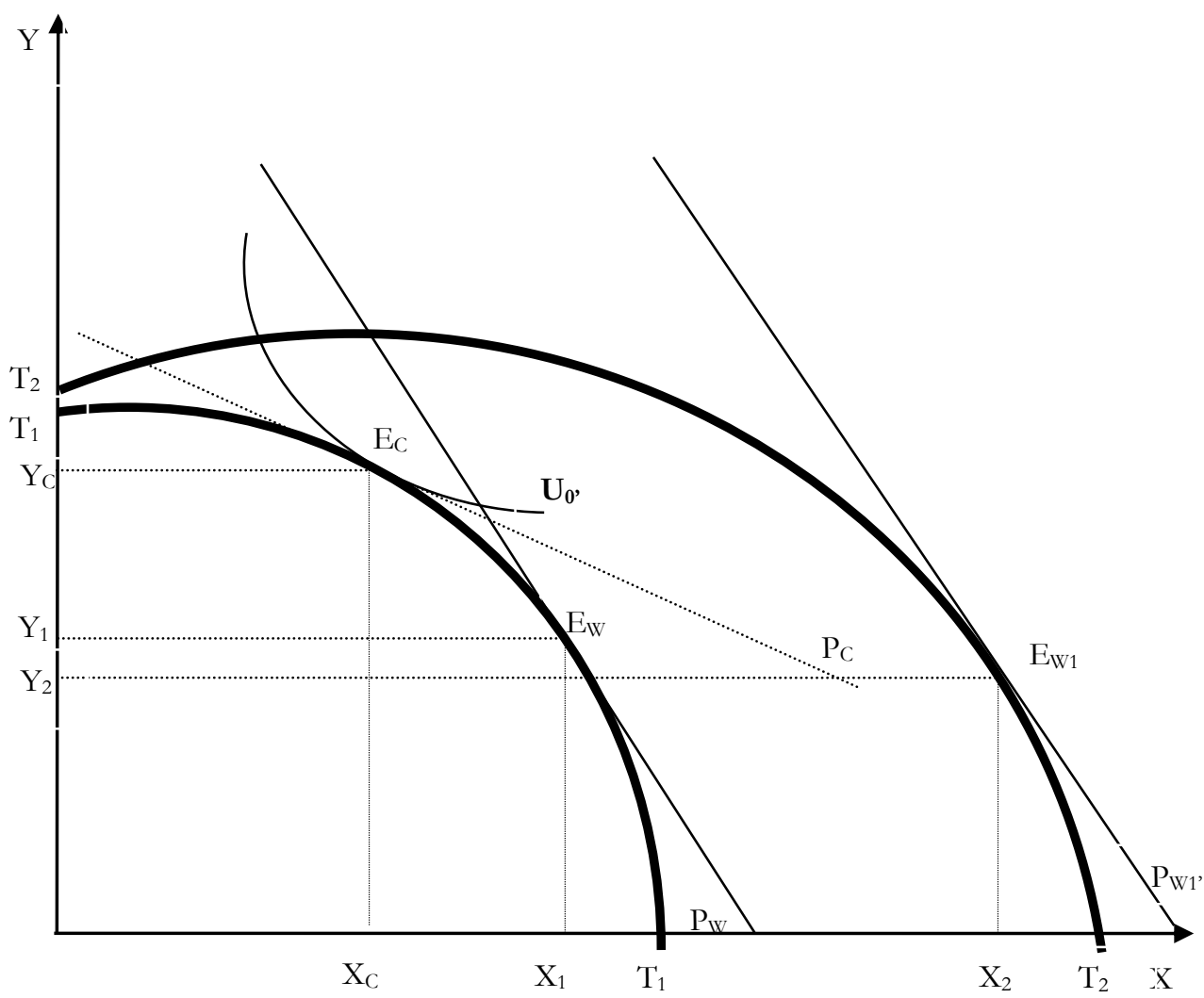

Źródło: opracowanie własne z wykorzystaniem: [Adebahr, Maennig, 1987, s. 68].

Chcąc wspierać rodzimą produkcję dobra Y, zostaje wprowadzona ochrona celna. Wraz z jej wprowadzeniem zmienia się krajowa relacja cen dwóch produktów - obecnie to linia PC. Widoczne jest to na krzywej transformacji - chroniona branża przemysłu jest w stanie wytworzyć znacznie więcej dobra $\mathrm{Y}$, kosztem produkcji dobra X. Punkt optymalnej produkcji dla dwóch krajowych przesuwa się z początkowego $\mathrm{E}_{0}$ do Ep. Gdyby założyć w tym momencie autarkię gospodarcza, to kraj ma zapewniona podaż pszenicy, a wyższa od cen światowych cena żelaza i stali redukuje popyt krajowy (konieczność importu). W ten sposób odbiorcy (kupujący żelazo) odczuwaja koszty ochrony celnej w postaci wyższych cen (kosztów produkcji), a tym samym ich krzywa obojętności $\mathrm{U}_{0}$ jest niżej położona i realizują mniejszą nadwyżkę konsumenta.

Wówczas krajowa relatywna cena żelaza również będzie wyższa od relatywnej ceny pszenicy. Stąd też producenci krajowi będą wytwarzać mniej pszenicy, której relatywna 
cena będzie niższa niż dla reszty świata. W warunkach całego świata może spaść podaż pszenicy, co doprowadzi do wzrostu jej ceny i poprawy terms of trade w kraju, kosztem zagranicy. Jak zauważa Krugman, skala efektu jest uzależniona m.in. od wielkości i potencjału produkcyjnego kraju, który chroni swój rynek w stosunku do reszty świata.

RYSUNEK 3.

\section{Argumenty na rzecz ochrony rodzimych, raczkujących branż gospodarki - efekt wprowadzenia cła wychowawczego}

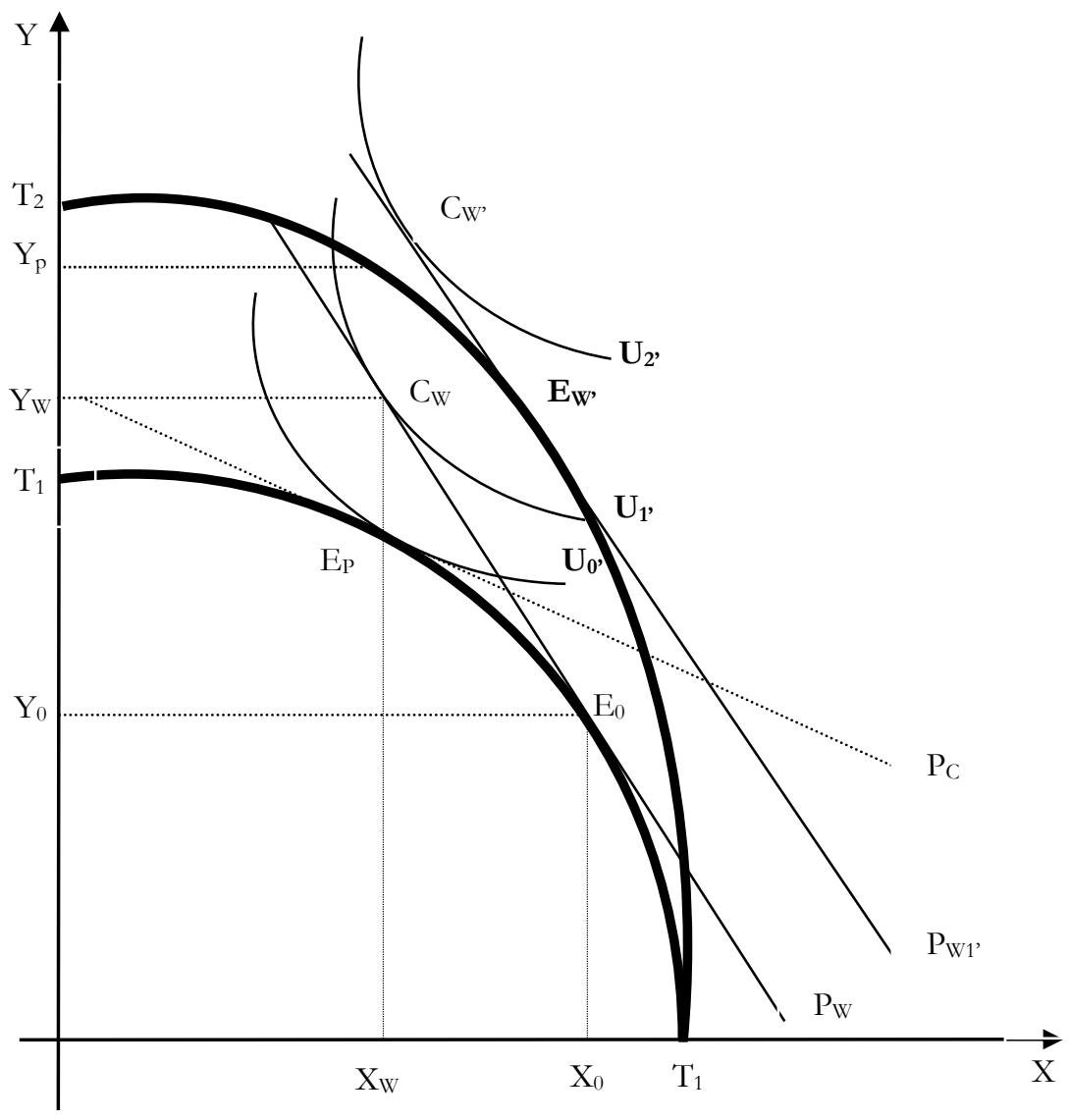

Źródło: opracowanie własne z wykorzystaniem: [Adebahr, Maennig 1987, s. 190-191].

Im kraj jest mniejszy i ma mniejszy udział w produkcji światowej, tym wpływ na światowy terms of trade będzie mniejszy [Krugman, Obstfeld, 1997, s. 94].

Jeśli mały kraj nakłada cła importowe, ale jego udział w wymianie chronionego towaru na rynku światowym jest nieznaczny, to redukcja importu ma raczej niewielki 
wpływ na cenę światową $\mathrm{w}$ tym znaczeniu cło importowe powiększa cenę produktu importowanego o pełną wielkość stawki celnej z $\mathrm{P}_{\mathrm{W}}$ do $\mathrm{P}_{\mathrm{w}+\mathrm{t}}$ (rysunek 4.).

Gdyby przyjąć, że przemysł krajowy jest objęty ochrona przez pewien okres, natomiast w kolejnym okresie taryfa celna jest w całości zlikwidowana, a chroniona gałąź przemysłu może produkować po cenie światowej $\mathrm{P}_{\mathrm{w}}$, to:

- gospodarstwa domowe osiagają taką samą nadwyżkę konsumenta, jak przed wprowadzeniem taryfy;

- $\quad$ rząd nie uzyskuje środków z opłat celnych;

- $\quad$ krajowi producenci przy cenie światowej $\mathrm{P}_{\mathbb{W}}$ wytworza wielkość produkcji $\mathrm{A}=\mathrm{D}_{1}-\mathrm{S}_{1}$

- $\quad$ kraj w dalszym ciagu będzie importował towar z zagranicy, $\mathrm{D}_{\mathrm{i}}=\mathrm{D}_{1}-\mathrm{A}$;

- $\quad$ krajowy przemysł, konkurując na rynku światowym, może pozyskiwać nowe rynki i rozszerzać potencjał produkcyjny.

Ponowne odniesienie do rysunku 3. obrazuje, że w wyniku procesu uczenia się, „rozlewania się wiedzy” krzywa transformacji ulega przesunięciu do $\mathrm{T}_{2}$. Przy założeniu, że wracamy do wolnej wymiany handlowej (założono, że terms of trade nie zmienia się), możliwości produkcyjne kraju wynoszą wówczas Ep1, a popyt krajowy na pszenicę $\mathrm{i}$ żelazo jest wyznaczony w punkcie $\mathrm{E}_{\mathrm{W}}$. W ten sposób analizowany kraj stanie się eksporterem żelaza, a importerem pszenicy.

Podstawowym pytaniem, wynikającym z przyjętych założeń, jest: dlaczego krzywa transformacji i (czy) przesunie się z położenia $T_{1}$ do położenia $T_{2}$ - jako efekt uczenia się, rozlewania wiedzy, efektów skali produkcji.

Z punktu widzenia szkoły klasycznej należy uwzględnić dwa czynniki dotyczące selektywności ochrony celnej:

- $\quad$ protekcja w postaci cła jest tymczasowa, stąd w analizie należy uwzględnić czas;

- protekcja jest wynikiem negatywnych efektów zewnętrznych, niedoskonałości w funkcjonowaniu rynku (np. brak zainteresowania rozwojem nowej branży ze strony sektora prywatnego), a tym samym interwencja rządu jest uzasadniona, nie hamuje i nie wypacza działania sił rynkowych.

To kryterium selektywności jest tzw. kryterium Bastable’a, czyli korzyści społeczne z prowadzenia ochrony celnej muszą pokryć społeczne koszty [Bahadir, 1984, s. 120].

Mimo procesu uczenia się, wzrostu kapitału społecznego, rozwoju mocy wytwórczych, klasycy preferują użycie innych narzędzi wspierania rozwijających się przemysłów.

Wskazują przy tym, że ochrona celna może być mało efektywna, ponadto rządy zainteresowane wsparciem i rozwojem nowych branż, np. przemysłu, powinny np. przekazywać pomoc publiczną zainteresowanym przedsiębiorstwom sektora prywatnego w budowie i rozwoju danej gałęzi, jednocześnie nie dyskryminując importerów i nie zakłócając wymiany handlowej. 
RYSUNEK 4.

Polityka wolnego handlu i infant industry - efekt wprowadzenia cła wychowawczego w małym kraju i późniejszego wzrostu krajowej podaży

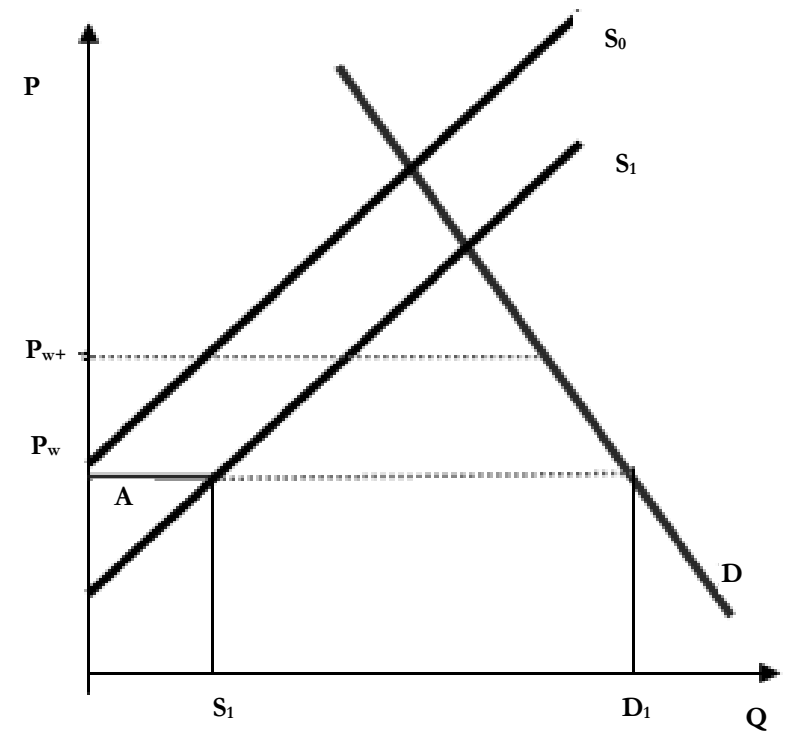

Źródło: opracowanie własne.

Klasycy podkreślają że wzrost ochrony celnej, a tym samym wzrost ceny dobra prowadzi do zniekształcenia bodźców ekonomicznych zarówno w odniesieniu do producentów, jak i konsumentów.

Jak pokazuja przeciwnicy ceł ochronnych, kraj wspierający rozwój danego przemysłu nie ma żadnej pewności, że w przeszłości nadal będzie mieć taką przewagę, co może być bolesne dla całej gospodarki i społeczeństwa. Ważnym argumentem, którego zdają się nie dostrzegać zwolennicy cła wychowawczego, jest to, że dany kraj, który decyduje się na takie narzędzie, nie musi koniecznie mieć przewagi komparatywnej w produkcji wybranego dobra. Wówczas ochrona celna będzie kosztownym narzędziem, które nie wpłynie na budowę przewagi komparatywnej.

\section{Cło wychowawcze - postulaty Friedricha Lista}

Argumenty ochrony „raczkujących” branż przemysłowych zostały przedstawione niewiele później niż teoria Smitha, m.in. przez A. Hamiltona (1790 rok). Hamilton jako sekretarz stanu USA pragnął promować młody, amerykański przemysł przetwórczy za pomoca ceł ochronnych (The Tariff Act of 1789). Ponadto, zdawał on sobie sprawę, jako doradca prezydenta Washingtona, że cła są ważnym źródłem przychodów państwa [List, 1910, s. 40]. Taryfy celne w USA były wielokrotnie zmieniane, 
dla przykładu lata 1824-1832 charakteryzowały się wysokim poziomem protekcji, np. produkty bawełniane i wełniane zostały obłożone cłem w wysokości 33,3\% wartości. W latach 1833-1842 można było dostrzec pewną liberalizację amerykańskiej taryfy celnej, aby w kolejnych latach 1843-1846 zauważyć powrót na ścieżkę protekcji. W tych ostatnich latach średnio taryfa celna wynosiła około $30 \%$, ale na produkty przemysłowe była ona znacznie wyższa. Na przykład taryfa celna na surówkę żelaza wynosiła $72 \%$, wytworzone produkty żelazne stanowiły $163 \%$, a produkty bawełniane $95 \%$.

W warunkach Stanów Zjednoczonych liberalizacja handlu nastapiła w 1846 roku, po wprowadzeniu taryfy celnej przez, ówczesnego sekretarza skarbu, Roberta Walkera (tzw. Walker-Tariff). Było to wynikiem koalicji plantatorów z Południa i producentów zbóż z Zachodu USA. W obliczu zniesienia corn laws przez Wielką Brytanię plantatorzy mieli możliwość eksportu produktów rolnych, a jednocześnie importu wyrobów przemysłu angielskiego na dogodnych warunkach. Ta polityka USA utrzymała się przez około 15 lat, ale wobec budowy własnego przemysłu, stany północne oczekiwały zaostrzenia polityki wolnego handlu.

Z poglądami klasyków ekonomii dotyczącymi liberalizacji wymiany międzynarodowej nie zgadzał się Friedrich List. Nie był on przeciwnikiem wolnego handlu, lecz uważał, że słabsza i mniej konkurencyjna gospodarka powinna być chroniona, aby w późniejszym czasie podjać konkurencję z innymi uczestnikami. Przykładem była sama Wielka Brytania w stosunku do wymiany handlowej z Holandią. Bairoch obrazowo podał, że w Europie na początku XIX wieku polityka wolnego handlu stanowiła nieliczne wysepki na otaczającym je oceanie protekcjonizmu.

Friedrich List rozwinął teorię wymiany w warunkach gospodarki krajów niemieckich. Stąd nie dziwi fakt, że w publikacji z 1904 roku W. H. Dawsona: pt.: Protection in various countries: Germany, autor wprost ocenił, że polityka fiskalna państw niemieckich, biorąc pod uwagę interesy przemysłu i rolnictwa późniejszego cesarstwa, z definicji miała charakter protekcjonistyczny [Dawson, 1904, s. 1 i n.]. Friedrich List profesor Uniwersytetu w Tybindze, który za głoszenie liberalnych haseł politycznych, w tym podżeganie przeciwko istniejącym instytucjom państwowym, został pozbawiony swojej katedry (w 1819 roku) i zmuszony do emigracji (w 1822 roku). W końcu uwięziony w twierdzy Asberg, zwolniony po kilku miesiącach pod warunkiem zrzeczenia się obywatelstwa i emigracji (do USA), był orędownikiem integracji politycznej i gospodarczej licznych państw niemieckich.

List opublikował swe słynne dzieło pt.: Das nationale System der politischen Oekonomie (w 1841 roku), w którym zawarł m.in. ocenę i stosunek do założeń szkoły klasycznej w ekonomii, a także do założeń wolnego handlu.

W charakterystyczny dla siebie sposób określił, że podstawą stworzonego przez niego systemu ekonomicznego, w odróżnieniu od klasyków ekonomii, jest naród. Podkreślał, że natura, charakter nacji wypełnia lukę pomiędzy indywidualnością a całą ludzkością w następujący sposób: Als charakteristischen Unterschied des von mir aufgestellten Systems bereichne ich die Nationalität. Auf die Natur der Nationalität als des Mittelgliedes zwischen Individualität und Menschbeit ist mein ganžes Gebäude gegründet (Charakterystycžna różnica przedsta- 
wionego przeze mnie systemu określitem naród. Na istocie narodu jako członu pomięşy indywidualniościa a ludzkościa opiera sie cała moja budowla (teoria)) [List, 1910, s. 40].

Friedrich List w trzydziestym drugim rozdziale (Das Tauschwertsystem Adam Smith) swojego dzieła akcentował, że A. Smith, tworząc teorię wymiany, zignorował naturę narodów, niemal całkowicie pomijając politykę i władzę państwową, zakładał wieczny pokój i powszechną unię, nie docenił rozwoju krajowych mocy produkcyjnych, a jednocześnie domagał się wolnego handlu [List, 1910, s. 454]. Ponadto, Smith stawiał na równi prywatna pomyślność z dobrobytem społecznym, natomiast List podnosił, jak ważnym elementem jest naród.

W trzydziestym czwartym rozdziale swojej pracy (Die Insularsuprematie und die deutsche Handelsunion) List przedstawił argumenty dotyczące ochrony rodzimego rynku. Ukazał jednocześnie narodowy interes wynikający z powstania Niemieckiego Związku Celnego (1834) i stosowania polityki ochrony wewnętrznego rynku przed konkurencja (głównie angielska) przez system ceł. Przywołał angielskiego ekonomistę J. Bowringa, dowodząc, że polityka wysokich ceł ochronnych dotycząca krajowych produktów przemysłowych jest właściwa, a same ceny chronionych towarów mogą być niższe niż zagranicznych. Podkreślał, że wewnętrzna konkurencja między krajowymi producentami, a w tym czasie ochrona przed konkurencją zagraniczna, może być czynnikiem prowadzącym do osiagnięcia cudu gospodarczego [List, 1910, s. 499-500]. Nie pozostawiał złudzeń, że wymiana handlowa kraju, opierająca się na eksporcie produktów rolnych i surowców, nie zapewni siły, dobrobytu i znaczenia takiego kraju. Kraj taki musi zabiegać o rozwój i wzrost produkcji przemysłowej, w tym wzrost eksportu produktów przemysłowych, przy jednoczesnym wzroście importu surowców [List, 1910, s. 70].

Friedrich List wyróżnił kilka stadiów w rozwoju gospodarki narodowej dotyczącej handlu zagranicznego, począwszy od najbardziej prymitywnych, skończywszy na najbardziej rozwiniętej (angielskiej) gospodarce. Zaliczył do nich następujące:

1. Rozwój kultury rolnej, w wyniku importu produktów przemysłowych i eksportu surowców i produktów rolnych;

2. Rozwój własnego (narodowego) przemysłu obok importu towarów z zagranicy;

3. Ochrona własnego przemysłu i w znacznej części własnego rynku produktów przemysłowych;

4. Eksport znacznej części krajowych produktów przemysłowych oraz import surowców i produktów rolnych [List, 1910, s. 271-273].

List ocenił, że kraje Niemieckiego Zwiazku Celnego osiagnęły w połowie XIX wieku trzecie stadium, stąd postulat ochrony własnego przemysłu [List, 1910, s. 513]. Równocześnie w wielu miejscach swojego dzieła wytykał Brytyjczykom ich politykę ochronną na przykładzie ustaw zbożowych, tak szkodliwą dla eksportu, np. pruskiej pszenicy.

W połowie lat trzydziestych XIX wieku państwa Niemieckiego Związku Celnego eksportowały do Anglii głównie produkty rolne oraz surowce, również importowały, obok produktów kolonialnych, produkty przemysłowe. Produkty gotowe niemieckiego przemysłu nie były w stanie konkurować z produktami angielskimi. Niemcy notowały ujemne saldo wymiany handlowej produktami gotowymi z: Anglia, Belgia, 
Francją, jednocześnie eksportowały dobra gotowe do takich części świata, które były jeszcze mniej rozwinięte, jak: Rosja/Królestwo Polskie, Austria, USA [Kutz, 1974, s. 252-262].

Jak szacuje Bairoch, w roku 1830 niemiecki przemysł miał udział w produkcji przemysłowej świata zaledwie 3\% [Bairoch, 1982, s. 296].

List zakładał, że w krótkim okresie rzeczywiście ceny chronionych, krajowych dóbr mogą wzrosnąć, ale w interesie narodowym jest, aby w wyniku konkurencji wewnętrznej ceny obniżyły się i aby w przyszłości z powodzeniem móc prowadzić otwarta wymianę handlowa (free trade).

Ochrona narodowego przemysłu poprzez wprowadzenie taryfy celnej powinna utrzymywać się do momentu, dopóki rodzimy przemysł może być narażony na oddziaływanie zagranicznej konkurencji. Stawki celne muszą wzrastać, jeśli krajowa konsumpcja obcych towarów przemysłowych będzie oparta w większości lub w zupełności na imporcie [List, 1910, s. 73].

Jednym z koronnych argumentów ochrony rodzimego rynku było stworzenie dogodnych warunków do budowy i rozwoju nowych gałęzi przemysłu, zwłaszcza w krajach mniej rozwiniętych. Twórcy teorii zwracali uwagę, że nowe przedsiębiorstwa miały niewielkie szanse skutecznej konkurencji z firmami majacymi siedzibę w krajach rozwiniętych (np.: w Wielkiej Brytanii, Belgii). Firmy z krajów rozwiniętych działały dłużej, a z czasem udało się im, obok wypracowania metod produkcji przemysłowej, zwiększyć swoją efektywność produkcji. Miały one lepszą jakość informacji i wiedzy na temat procesu produkcji, lepiej znały rynek, w tym rynek pracy, a co najważniejsze, ich produkty mogły być relatywnie tańsze od „nowych przybyszów”. W efekcie istniejące firmy były w stanie sprzedawać swój towar po niższej cenie na rynkach międzynarodowych i mieć nadal opłacalną produkcję.

\section{Rozwój i ochrona celna przemysłu hutniczego Niemiec na przykładzie produkcji surówki żelaza}

Na początku XIX wieku surówka żelaza jako niezbędny surowiec dla innych branż pozostawała ważnym elementem rozwoju przemysłu Niemiec. Zarówno zasoby węgla kamiennego, jak i rodzime zasoby rud żelaza, przy relatywnie drogim transporcie, miały decydujące znaczenia dla rozwoju tego sektora. W połowie XIX wieku kraje niemieckie w porównaniu z innymi krajami posiadały tak złoża węgla, jak i rud żelaza, choć położenie (odległość) kopalń względem siebie w wielu przypadkach nie było korzystne. Rozbudowa wielkich pieców hutniczych postępowała, ale koszt pozyskania kapitału i odsetki były ciagle wysokie.

Rodzima podaż artykułów przemysłu hutniczego niezbędnych do rozwoju jednego z największych państw niemieckich Prus, w tym surówki żelaza, była w XVIII i w pierwszych dekadach XIX wieku ciagle niewystarczająca [Kestner, 1902, s. 1 i n.]. Zgodnie z pruską taryfą celną z 26 maja 1818 roku (i w latach kolejnych), została zniesiona opłata celna na import tego surowca. Gospodarka pruska, będąca w tym czasie w drugim stadium rozwoju Lista, potrzebowała relatywnie taniego surowca (surówki żelaza). 
Dopiero w 1844 roku w obliczu kryzysu gospodarczego oraz rozwoju krajowego przemysłu i silnej konkurencji ze strony angielskich produktów na obszarze państw zrzeszonych w Deutscher Zollverein wprowadzono cło w wysokości 20 marek (RM) od każdej tony surówki. Ochrona celna umożliwiła rozwój i postęp w niemieckim hutnictwie. Cło zostało obniżone dopiero w 1865 roku po podpisaniu umowy handlowej z Francją i wynosiło 15 RM, zaś po podpisaniu umowy handlowej z Austria (w 1868 roku) spadło do 10 RM. Nowa taryfa celna z 1870 roku, która była efektem polityki wolnego handlu, zakładała spadek cła na surówkę żelaza do $5 \mathrm{RM}$ za tonę. W tym czasie nastąpił ogromy postęp w niemieckim przemyśle hutniczym, ale także wzrosło zapotrzebowanie na surówkę żelaza - wzrastał popyt ze strony kolejnictwa, przemysłu maszynowego. Mimo rozbudowy wielkich pieców hutniczych, ciagle ważnym elementem uzupełniania niedoboru surowca pozostawał import m.in. z Anglii. Od października 1873 roku zniesiono taryfę celną na wwóz surówki.

Kryzys gospodarczy w 1873 roku, który dotknął kraje uprzemysłowione, a w tym Niemcy, byl przyczyną odwrócenia typowej dla lat sześćdziesiątych XIX wieku ery wolnej wymiany handlowej na epokę protekcjonistyczna.

Epokę wolnego handlu można uznać za korzystną dla gospodarki Niemiec, jak zauważa Kestner, państwo pruskie wysyłało swoje nadwyżki żywności (w tym ziarna) do innych krajów, co pozwoliło uzyskiwać znaczne środki finansowe, nawet w przypadku zacofanych gospodarczo Prus Wschodnich. Sytuacja zmieniła się wraz z napływem relatywnie tańszego ziarna z Ameryki do Europy, wówczas Niemcy (Prusy), będąc eksporterem zbóż, stawały się ich importerem. Rosło niezadowolenie producentów zbóż (w tym junkrów pruskich).

Impulsem do zmiany taryfy celnej, obok żądań junkrów, była także konieczność zapewnienia dochodów Rzeszy Niemieckiej. Nie bez znaczenia były również żądania wzmocnienia ochrony celnej ze strony przemysłowców, w tym przemysłu ciężkiego. Następstwem żądań było wprowadzenie w 1879 roku nowej taryfy celnej, zgodnie z którą na wwóz surówki żelaza wprowadzono cło w wysokości $10 \mathrm{RM} / 1$ tonę.

W zasadzie w 1873 roku państwa zrzeszone w Niemieckim Związku Celnym wytwarzały ponad 2,2 mln ton surówki żelaza, co stanowiło już 14,9\% produkcji światowej. Niemcy były, poza Wielką Brytanią, największym eksporterem surówki żelaza.

Kryzys w 1873 roku i zmniejszone zapotrzebowanie na surówkę żelaza oraz spadające ceny (cena 1 tony spadła ze 170 RM do $50 \mathrm{RM}$ ) przyczyniły się do ciężkiej sytuacji przemysłu - nadprodukcji i strat przy relatywnie wysokich kosztach produkcji. W 1873 roku Niemcy importowały blisko 690 tys. ton surówki, co stanowiło blisko $32 \%$ krajowej produkcji. Na krajowym rynku szczególnie duży był udział angielskiej surówki żeliwnej, w 1873 roku wyniósł on $72,9 \%$. Angielska surówka odlewnicza była ciagle tańsza niż niemiecka - szczególnie w części północnej Niemiec. Zupełnie inaczej przedstawiała się sytuacja surówki pudlowanej - w 1878 roku udział surówki z zagranicy wynosił zaledwie 2,5\% [Kestner, 1902, s. 1 i n.].

Chcąc porównać stan niemieckiego i angielskiego hutnictwa żelaza w latach siedemdziesiątych XIX wieku, należy wskazać, że:

1. Anglia, używając w hutnictwie żelaza własnych rud w procesie wytopu żelaza, notowała niże koszty produkcji. Rudy angielskie były wolne od domieszki fos- 
foru, do tego wielkie piece były położone blisko rzek i morza. Import hiszpańskiej rudy był także tańszy przy geograficznym położeniu Anglii. Nawet przy porównaniu tym, że huty niemieckie i angielskie byłyby skazane na tę samą rudę żelaza z Hiszpanii, koszt produkcji 1 tony surówki w Anglii byłby niższy o około 19 RM. Przy spadku ceny surówki i spadku popytu cena jednostkowa była decydująca;

2. Położenie względem siebie znanych złóż węgla i rud żelaza było dużo korzystniejsze w Anglii. Koszty transportu do hut z reguły również były niższe niż w Niemczech;

3. Leżąca w pobliżu szlaków wodnych Anglia, w tym niewielka odległość do portów w Basenie Morza Północnego i Bałtyckiego, sprawiała, że po uwzględnieniu kosztów frachtu angielska surówka była tańsza (łącznie z okręgiem berlińskim) od surówki z Westfalii i Śląska;

4. Anglia miała większe doświadczenie w wytopie żelaza, w tym dużo bardziej świadomą i przyuczoną kadrę pracowników. To skutkowało tym, że mimo wyższych wynagrodzeń w Anglii, wydajność jednostkowa w Anglii była także wyższa;

5. Marka, wysoka jakość sprawiały, że angielskie wyroby przemysłu hutniczego były cenione i cieszyły się dobrą renomą u importerów;

6. Rozwinięty rynek kredytowy, dostępny kapitał, dobrze rozwinięty transport, polityka handlowa były nieporównywalnie lepsze od rodzących się wzorców niemieckich [Kestner, 1902, s. 9-11].

Przytoczone argumenty przyczyniły się do tego, że niemieccy przemysłowcy i politycy byli przekonani, że wobec braku ochrony celnej niemieckie hutnictwo stoi na przegranej pozycji.

Wprowadzona taryfa celna w wysokości 10 RM określała odpowiednio: 20\% ceny dla wysokojakościowej surówki odlewniczej, $25 \%$ dla surówki odlewniczej i około $15 \%$ dla surówki besemerowskiej. Oznaczało to, że taryfa celna rekompensowała mniej lub bardziej wyższe koszty produkcji w Niemczech.

Wdrożenie ochrony celnej w 1879 roku zbiegło się z wynalazkiem Thomasa i Gilchrista, natomiast oba te czynniki należałoby wziąć po uwagę przy analizie stanu hutnictwa żelaza w Niemczech.

$\mathrm{Z}$ jednej strony ochrona celna wiązała się ze wzrostem cen surówki zagranicznej, ale zarazem wynalazek Thomasa mógł wywołać spadek kosztów produkcji. Wynalazek Thomasa-Gilchrista polegał na wykorzystaniu gruszki Bessemera do wyprawy materiału zasadowego (początkowo wapno ze szkłem wodnym, a od 1878 roku dolomit palony z domieszką glinki). Wynalazek przyczynił się do spadku kosztów produkcji, zapewniając mniej kosztowna ekstrakcje fosforu, co spowodowało rozwój hutnictwa w Westfalii [Buzek, 1933, s. 22-23]. Koszt wytopu surówki (żeliwa) spadał nawet o $4 \mathrm{RM} / 1$ tonę. W zasadzie w przypadku żeliwa dużo większą rolę dla rozwoju sektora odegrał wynalazek Thomasa i niższe koszty produkcji, niż sama ochrona celna (cena za 1 tonę surówki po 1879 roku nie wzrosła), [Kestner, 1902, s. 25].

Największe znaczenie ochrony celnej miało zastosowanie w przypadku surówki odlewniczej. Zostało to zobrazowane na rysunku 5. Porównano cenę surówki od- 
lewniczej pierwszej klasy z importu (szkockiej) i rodzimej (westfalskiej). W zasadzie tylko w latach 1883-1887 i 1899 cena surówki szkockiej (po uwzględnieniu cła) była wyższa o ponad $10 \mathrm{RM}$. W pozostałych latach różnica cenowa była mniejsza niż obowiązujące cło. To dzięki ochronie celnej surówka szkocka pozostawała ciagle droższa.

Co ciekawe, mimo ochrony celnej, był zauważalny spadek cen surówki (lata: 1881-1886, 1890-1893).

RYSUNEK 5.

\section{Cena surówki odlewniczej: 1. klasa - surówka importowana (szkocka)} i w Westfalii na tle cła ochronnego

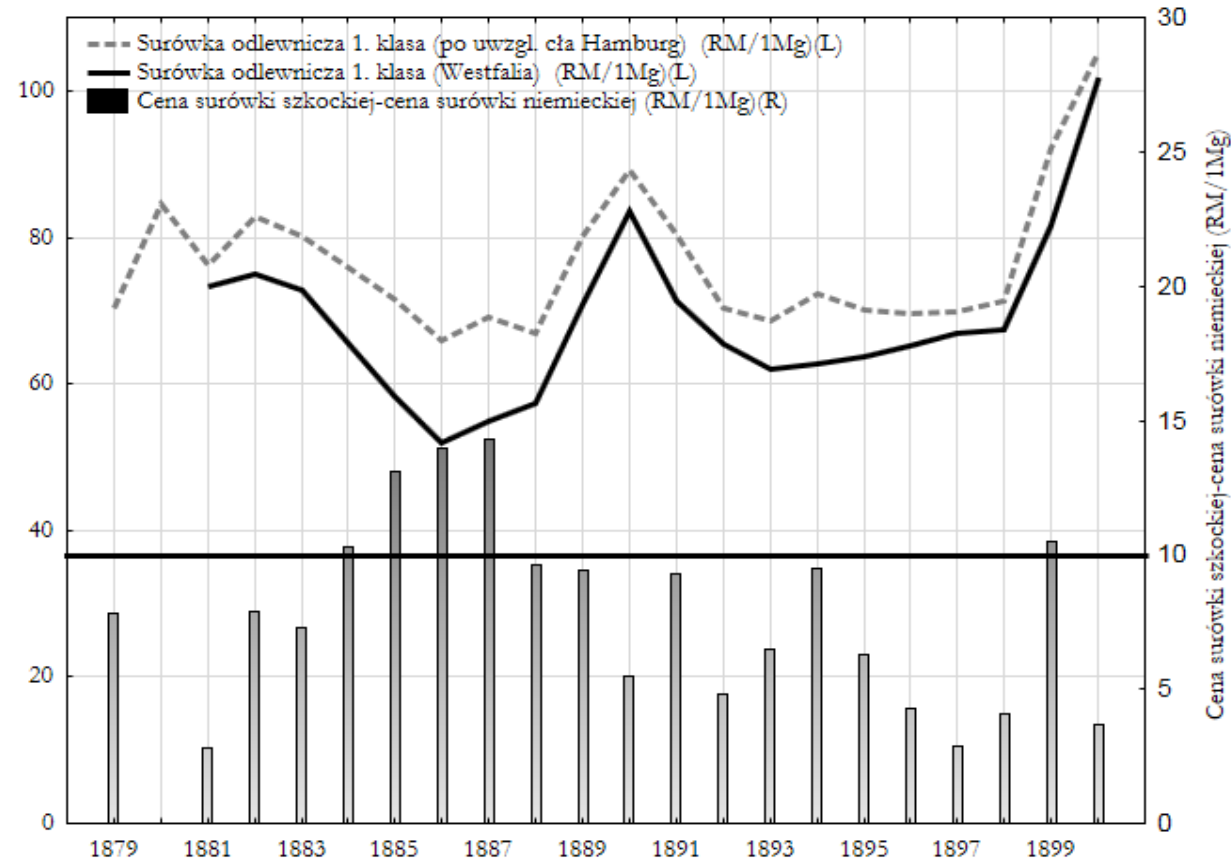

Źródło: opracowanie własne na podstawie: [Kestner, 1902, s. 27].

Obok ochrony celnej, w hutnictwie niemieckim także zachodziły ogromne zmiany, które wpływały na redukcję kosztów produkcji. Należałoby w tym miejscu podać następujące przesłanki:

1. Niższe koszty pozyskiwania surowców (rudy, koks);

2. Zwiększenie poziomu wykorzystania surowców;

3. Uzyskiwanie produktów ubocznych, będących dodatkowym źródłem dochodów (szlaka, amoniak);

4. Bardziej efektywna siła robocza (spadek kosztów w przeliczeniu na jednostkę produktu - dla przykładu w roku 1879 roku średnio do produkcji 1000 ton zaangażowanych było 7,5 pracowników, zaś w na początku 1900 roku już tylko 4,5 pracowników), [Kestner, 1901, s. 36]. 
5. Wyższy poziom organizacji i zarządzania;

6. Większa efektywność i rozszerzenie rynków zbytu (w tym eksportu);

7. Rozwój i niższe koszty transportu;

8. Postęp techniczny i nowe wynalazki [Kestner, 1902, s. 30-31].

Czynniki te miały niebagatelny wpływ na rozwój niemieckiego przemysłu hutniczego (obok analizowanej ochrony celnej). Dla przykładu, postęp techniczny prowadził do tego, że np. większe piece hutnicze (z około 16-18 m do 20-22 m) umożliwiały zwiększenie wydajności dziennej z 40-60 ton do 100-160 ton. W latach 1878-1900 zmniejszono także zużycie koksu o około 200-300 kilogramów na każdą wytopioną tonę surówki.

W zasadzie ochrona celna i pozostałe czynniki, mające wpływ na efektywność produkcji, przyniosły wzrost możliwości produkcyjnych surówki żelaza. Najlepiej obrazuje to rysunek 6. Ewidentnie wzrastał udział Niemiec w światowej produkcji surówki żelaza i tuż przed wybuchem I wojny światowej wyniósł on 25\%.

RYSUNEK 6.

Udział Niemiec w światowej produkcji surówki żelaza w latach 1825-1913 (w \%)

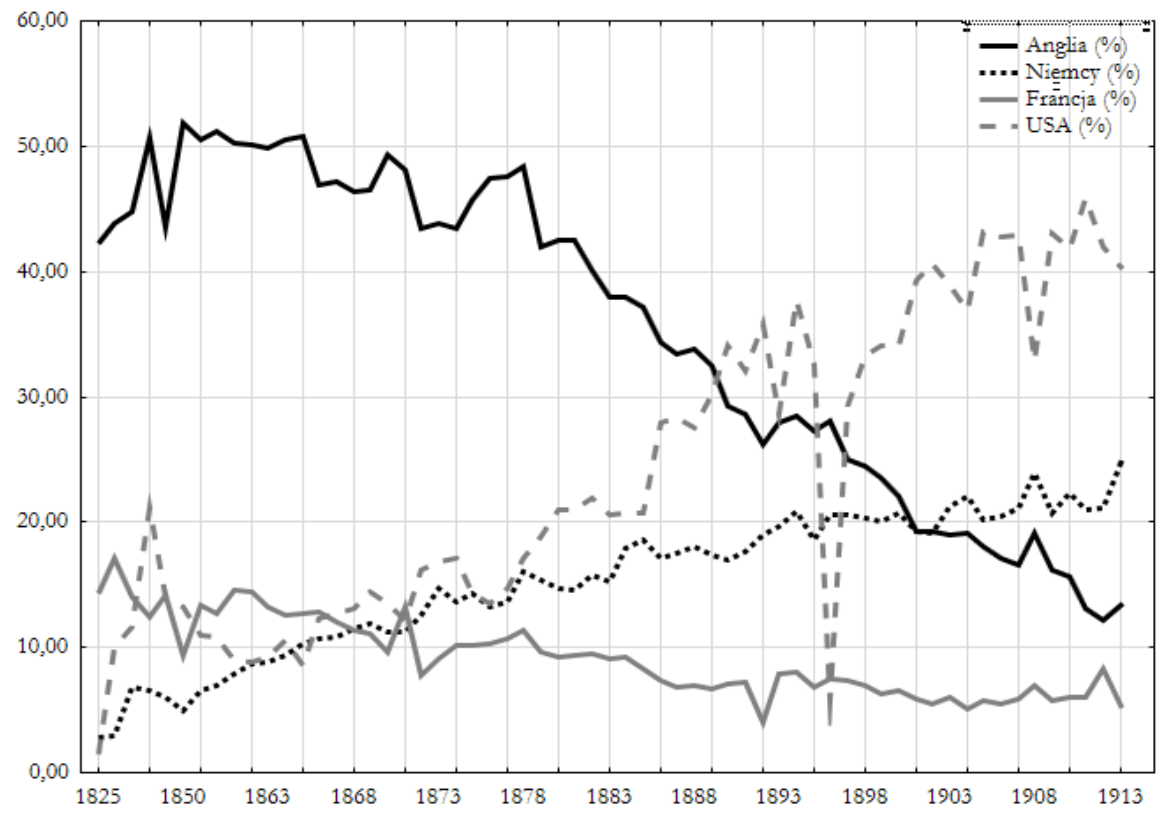

Źródło: opracowanie własne na podstawie: [Meisner, 1929, s. 84 i n.].

\section{Podsumowanie}

Mimo upływu lat, cło wychowawcze jest nadal ważnym narzędziem w prowadzeniu polityki handlowej. 
Kraje aspirujące do grona krajów rozwiniętych, a będące jeszcze słabo uprzemysłowione, moga posiadać potencjalna przewagę komparatywną w przemyśle, ale raczej nie mogą skutecznie konkurować $\mathrm{z}$ krajami już rozwiniętymi. Zwolennicy infant industry w XIX wieku uważali, że dzięki stymulowaniu produkcji krajowej i czasowej ochronie celnej, krajowy przemysł zwiększy swą wydajność. Rezygnacja z tego narzędzia, wobec braku stosowania znanych dziś innych mechanizmów wspierania rodzimej produkcji, jak np.: polityki kredytowania firm, kwot ilościowych, wpierania polityki proeksportowej, w rezultacie mogłaby oznaczać „zdanie się” jedynie na wyroby przodujących branż z innego kraju.

Nie bez powodu autor wykazał, że USA, Niemcy, a także sama Wielka Brytania w XIX wieku powszechnie stosowały politykę protekcjonizmu - w postaci cła wychowawczego. Jak podaje Krugman, Japonia również do lat siedemdziesiatych XX wieku prowadziła rozbudowaną kontrolę importu.

Jednocześnie należy podkreślić, że Niemcy, mimo dużej zmienności w zmianie wysokości stawek celnych, także dotyczących kluczowych sektorów (przemysł ciężki, w tym żelaza i stali) prezentowanych w artykule, pozostawały krajem, który nie stosował, aż tak wysokiej ochrony celnej, jak USA czy Wielka Brytania, a swój sukces gospodarczy zawdzięczal równocześnie innym determinantom, w tym aktywnemu udziałowi państwa [Chang, 2003, s. 7]. Należy dodać, że sektor hutnictwa żelaza, szczególnie ważny dla potęgi gospodarczej Niemiec, miał duży wpływ na rozwój przemysłu maszynowego oraz sektora kolejowego [Myszczyszyn, 2013]. Za sprawą ochrony celnej, co uzasadnił autor, niemiecka surówka żelaza pozostawała tańsza od konkurencji zagranicznej, zmniejszył się import surówki zagranicznej, a to dawało przewagę niemieckiemu przemysłowi hutniczemu na rynku krajowym i było przede wszystkim istotne w latach gospodarczo słabszych. W równym stopniu rodzimy przemysł dzięki nowym wynalazkom, procesowi uczenia się i innym przesłankom dążył do redukcji kosztów produkcji i umacniania swojej pozycji na rynkach międzynarodowych.

Cło wychowawcze, mimo sceptycyzmu ze strony ekonomii klasycznej, odegrało pewną rolę w rozwoju gospodarczym wyżej przywołanych krajów.

Jak dowiódł autor, pod względem teoretycznym model cła wychowawczego jest poprawny [por. Rynarzewski, 2003, s. 91-106], choć powszechnie był krytykowany przez nurt klasyczny w ekonomii, przy zupełnie innym podejściu nurtu merkantylistyczno-keynesowskiego. Umiejętne wykorzystanie tego narzędzia może przynieść w przyszłości pewne pozytywne skutki rozwoju danego przemysłu. Niemniej polityka taka musi zachodzić z wielką ostrożnością i rozwaga, a w określonej sytuacji politycznej i wobec nacisku zainteresowanych grup producentów może to być trudne do realizacji. Jednak efektem docelowym prowadzenia tymczasowej polityki ceł ochronnych w zasadzie powinna być wolna wymiana handlowa.

\section{Literatura}

Adebahr H., Maennig W. 1987 Außenhandel und Weltwirtschaft, Duncker \& Humblot, Berlin. 
Bahadir S. 1984 Theorien und Strategien der regionalen Wirtschaftsintegration von Entwicklungsländern, Duncker \& Humblot, Berlin.

Bairoch P. 1993 Economics and World History - Myths and Paradoxes, Wheatsheaf, Brighton.

Bairoch P. 1982 Industrialization Levels from 1750 to 1980, „Journal of European Economic History", 11.

Buzek J. 1933 Rozbudowa techniczna żelazo-hutnictwa polskiego w ostatnich 10 latach na tle rozwoju hutnictwa w ogóle, Wydawnictwo E. Mirek i Spółka, Sosnowiec.

Capie F. 1994 Tariffs and growth: some illustrations from the world economy, 1850-1940, Manchester University Press, Manchester.

Dawson W. H. 1904 Protection in various countries: Germany, King \& Son Orchard House Westminster, London.

Dormois J. P. Lains P. 2006 Classical Trade Protectionism 1815-1914, Taylor \& Francis e- Library.

Kicking Away the Ladder: The "Real" History of Free Trade, FPIF Special Report, Chang Chang H., December 2003, dokument elektroniczny, tryb dostępu: [http://www.ilocarib.org.tt/trade/documents/economic_policies/SRtrade2003. pdf, data wejścia: 15.12.2014].

Kestner F. 1902 Die deutschen Eisenzölle 1879-1900, [in:] Staats- und socialwissenschaftliche Forschungen, G. Schmoller (ed.), Bd. 21, z. 3, Wydawnictwo Druncker und Humblot, Leipzig.

Krugman P. R. Obstfeld M. 1997 Miedzynarodowe stosunki gospodarcze, Wydawnictwo Naukowe PWN, Warszawa.

Kuliszer J. 1961 Powszechna historia gospodarcza średniowiecz̧a i czasów nowożytnych, t. II, KiW, Warszawa.

Kutz M. 1974 Deutschlands Aussenhandel, Deutschlands Aussenbandel von der Französischen Revolution bis zur Gründung des Zollvereins 1787-1833. Eine statistische Strukturuntersuchung zur vorindustriellen Zeit, Franz-Steiner-Verlag, Wiesbaden.

Lampe M. 2008 Bilateral Trade Flows in Europe, 1857-1875. A new dataset, [in:] Research in Economic History, A. Field, G. Clark, W. Sundstrom (eds.), JAI Press, Bingley.

McKee S. 1934 Papers on Public Credit, Commerce and Finance, Colombia University Press, New York.

Meisner M. 1929 Die Versorgung der Weltwirtschaft mit Eisen und Stabl 1860 bis 1926, Ferdinand Enke Verlag, Stuttgart.

Mitchell B. 1988 British Historical Statistics, Cambridge University Press, Cambridge.

Myszczyszyn J. 2013 Wpływ kolei żelaznych na wzrost gospodarczy Niemiec 1840-1913, Wydawnictwo Uniwersytetu Łódzkiego, Łódź.

Ohlin B. 1933 Interregional and International Trade, Harvard University Press, Cambridge.

Ricardo D. 1957 Zasady ekonomii politycznej i opodatkowania, Wydawnictwo Naukowe PWN, Warszawa.

Rynarzewski T. Zielińska-Głębocka A. 2006 Mięzynnarodowe stosunki gospodarcze. Teoria wymiany i polityki handlu międzynarodowego, Wydawnictwo Naukowe PWN, Warszawa. 
Rynarzewski T. 2003 Cto wychowawcze $i$ cto optymalne w teorii i praktyce polityki handlu miedzynarodowego, Ruch Prawniczy, Ekonomiczny i Socjologiczny, Rok LXV/1.

Smith A. 1954 Badania nad natura i prayczynami bogactwa narodów, Wydawnictwo Naukowe PWN, Warszawa.

Viner J. 1953 International trade and economic development, Clarendon, Oxford. 